\title{
PEMBINAAN KEAGAMAAN BAGI TUKANG BECAK \\ MELALUI MAJELIS TAKLIM ABANG BECAK (MATABACA) \\ NURUL HAYAT JEMBER
}

\author{
Shofiyah Zahro' \\ Prodi PAI FTIK IAIN Jember \\ shofifiya17@gmail.com \\ Diambang Fajar Ahwa \\ Prodi PAI FTIK IAIN Jember \\ diambangfajar@gmail.com
}

\begin{abstract}
Abstrak
Penelitian ini bertujuan untuk mendeskripsikan pembinaan keagamaan bagi tukang becak melalui majelis taklim abang becak (Matabaca) Nurul Hayat Jember. Penelitian ini menggunakan pendekatan kualitatif dengan jenis penelitian lapangan (field research). Teknik pengumpulan data yang dilakukan yaitu menggunakan observasi, wawancara dan dokumentasi. Keabsahan data yang digunakan yaitu triangulasi sumber dan triangulasi teknik. Penelitian ini memperoleh kesimpulan : (1) Pembinaan keagamaan dalam kehidupan tukang becak melalui Matabaca Nurul Hayat Jember diantaranya meliputi pembinaan akidah, pembinaan ibadah, dan pembinaan akhlak. (2) Metode yang digunakan dalam pembinaan keagamaan bagi tukang becak di Matabaca Nurul Hayat Jember adalah metode ceramah, tanya jawab dan demonstrasi. (3) Tujuan pembinaan keagamaan bagi tukang becak melalui Matabaca Nurul Hayat Jember adalah untuk memberdayakan ekonomi jamaahnya, untuk mengembangkan pengetahuan agama dan merubah sikap, tingkah laku serta kehidupan beragama para jamaahnya menjadi lebih baik, untuk menumbuh kembangkan sikap positif dan disiplin terhadap agama, serta untuk memberikan ruang kepada jamaah agar diakui keberadaanya oleh masyarakat melalui majelis taklim yang mampu memberikan kegiatan positif di dalamnya.
\end{abstract}

Kata kunci: pembinaan keagamaan, majelis taklim

\begin{abstract}
This study aims to describe the religious guidance of pedicab drivers through the Majelis Taklim Abang Becak (Matabaca) Nurul Hayat Jember. This research uses a qualitative approach with the type of field research. The data collection technique used was observation, interview and documentation. The validity of the data used were source triangulation and technical triangulation. This research draws the following conclusions: (1) Religious guidence in the life of a pedicab drivers through Matabaca Nurul Hayat Jember includes fostering faith, fostering worship, and building moral. (2) The method used in religious guidance for pedicab drivers in
\end{abstract}




\section{AL-ADABIYAH: Jurnal Pendidikan Agama Islam}

Matabaca Nurul Hayat Jember is a lecture methods, questions and answers and demonstrations. (3) The aim of religious guidance for pedicab drivers through Matabaca Nurul Hayat Jember is to empower the congregation's economy, to develop religious knowledge and to changing attitudes, behavior and religious life of the congregations is to be better, to develop positive attitudes and discipline of religion, and to provide space for the congregation to acknowledge their existence by the community through majelis taklim which are able to provide positive activities in it.

Keywords: religious development, majelis taklim.

\section{Pendahuluan}

Agama merupakan aturan-aturan dari Tuhan yang Maha Esa, petunjuk bagi hambaNya agar dapat selamat, sejahtera dan bahagia dalam menjalani kehidupannya di dunia maupun di akhirat sesuai petunjuk yang telah ditetapkan serta teladan-teladan Nabi terdahulu beserta kitabnya. ${ }^{1}$

Islam sebagai cahaya dan petunjuk bagi seluruh umat manusia, bukan hanya untuk satu kaum ataupun golongan tertentu. Agama Islam adalah milik semua manusia yang ada di muka bumi, tanpa mengkhususkan hanya untuk bangsa Arab saja yang merupakan tempat diturunkannya agama ini. ${ }^{2}$ Dalam hal ini pula, pendidikan agama Islam merupakan bagian integral dari program pengajaran pada setiap jenjang dan lembaga pendidikan serta merupakan usaha dan pembinaan pendidikan dalam memahami, menghayati serta mengamalkan ajaran agama Islam sehingga menjadi manusia yang bertaqwa dan warga negara yang baik. Islam sebagai agama yang menjadi pedoman hidup bagi manusia dan mencakup seluruh kehidupan manusia.

Di samping sebagai pedoman hidup, Islam merupakan ajaran yang harus didakwahkan dan memberikan pemahaman berbagai ajaran yang terkandung di dalamnya. Seperti ajaran agama Islam dalam pembinaan umat manusia, yang menjadikannya sebagai makhluk yang sempurna. Sarana yang dapat dilakukan untuk menyalurkan dan menyebarkan nilainilai ajaran agama Islam tersebut diantaranya melalui majelis taklim yang

${ }^{1}$ Ahmad D. Marimba, Pengantar Filsafat Islam, (Bandung: PT. Al-Ma'arif, 1989), 128

2 Muhammad Alim, Pendidikan Agama Islam, (Bandung; PT Remaja Rosdakarya, 2006), 104 


\section{AL-ADABIYAH: Jurnal Pendidikan Agama Islam}

berfungsi memberikan pemahaman tentang nilai-nilai ajaran agama Islam kepada sesama manusia.

Majelis taklim merupakan salah satu wadah yang cukup efektif dan efisien untuk melakukan interaksi dan mensosialisasikan ajaran Islam bagi penganutnya. Kegiatan ini dilakukan baik melalui lisan, tulisan maupun perbuatan nyata. ${ }^{3}$

Menurut Aswary Rahmat ${ }^{4}$, majelis taklim menjadi sarana dakwah dan tabligh yang Islami. Hal tersebut disebabkan karena kedudukan serta fungsi yang dimiliki oleh majelis taklim mengarah kepada pembinaan dan peningkatan kualitas hidup sesuai tuntutan ajaran Islam.

Abdul Mu'in di dalam jurnal yang ditulisnya dengan judul "Fenomena Pendidikan Keagamaan Masyarakat Tabanan Bali; Kasus Majelis Taklim AlFalah"5 Ia berbendapat bahwa majelis taklim merupakan institusi pendidikan keagamaan non formal dan sekaligus sebagai lembaga dakwah yang memiliki peran penting dalam pembinaan kehidupan beragama, terutama dalam mewujudkan learning society, suatu masyarakat yang memiliki tradisi belajar tanpa dibatasi oleh usia (long life education), jenis kelamin, tingkat pendidikan, dan status sosial serta dapat menjadi wahana belajar pendidikan keagamaan, silaturahim dan wahana yang efektif untuk menyampaikan pesan-pesan pendidikan keagamaan. Majelis taklim menjadi alternatif untuk mendapatkan pendidikan ilmu agama bagi mereka yang tidak memiliki cukup tenaga, waktu dan kesempatan untuk menimba ilmu agama di jalur pendidikan formal. Inilah yang menjadikan majelis taklim memiliki karakteristik tersendiri dibandingkan pendidikan-pendikan nonformal pada umumnya.

${ }^{3}$ M. Munir, Wahyu Ilahi, Manajemen Dakwah, (Jakarta: Rahmat Semesta, 2006), 2

4 Aswary Rahmat, , Skripsi: Peranan Majelis Taklim Al-Munawwarah dalam Pembinaan Masyarakat Di Kelurahan Mosso Dhua Kecamatan Sendana Kabupaten Majene Provinsi Sulawesi Barat (Makassar; UIN Alaudin Makasar, 2018), 2

5 Abdul Muin, Fenomena Pendidikan Keagamaan Masyarakat Tabanan Bali; Kasus Majelis Taklim Al- Falah, Jurnal Penelitian Pendidikan Agama dan Keagamaan Vol. 6, No 3 (Juli- September 2008), 68 


\section{AL-ADABIYAH: Jurnal Pendidikan Agama Islam}

Berdasarkan situs web resmi Nurul Hayat ${ }^{6}$, para Abang becak adalah contoh komunitas kehidupan jalanan. Kadang karena lingkungan yang keras dan kebutuhan akan segenggam beras, membuat mereka tak punya waktu mengasah ruhaniah mereka. Dan ketika jalan takwa tidak dirajut sama sekali, hatipun semakin buta. Maka tak jarang kita melihat di pangkalan becak mereka mengisi waktunya dengan bermain kartu, merokok, dan perilaku negatif lainnya. Sabda Nabi SAW bahwa "Kemiskinan mendekatkan pada kekafiran" menjadi benar apabila melihat keadaan tersebut.

Para abang becak ini sangat membutuhkan siraman rohani yang harus dilakukan oleh para da'i yang lebih luas pengetahuan dan ilmu agamanya. Ditengah perkerjaan harian mereaka sebagai tukang becak, mereka juga sangat membutuhkan ilmu agama yang dijadikan sebagai pedoman dan petunjuk untuk menjalani kehidupan sebagai hamba Allah yang baik.

Yayasan Nurul Hayat merupakan lembaga dakwah tergerak untuk menyentuh kehidupan agama mereka melalui majelis taklim bernama "MATABACA" yang merupakan singkatan dari Majelis Taklim Abang Becak.

Dengan pendekatan kekeluargaan akhirnya Nurul Hayat berhasil menyatukan para abang becak dalam kelompok-kelompok pengajian. Setiap bulan, mereka menyisihkan waktu untuk datang ke masjid-masjid tempat dilaksanakannya majelis taklim. Sebagai apresiasi atas kesedian mereka untuk mengaji, Nurul Hayat memberikan layanan berobat gratis, pinjaman tanpa bunga, dan santunan hari raya.

Tujuan penelitian ini adalah. Pertama, untuk mendeskripsikan pembinaan keagamaan dalam kehidupan bagi tukang becak melalui Majelis Taklim Abang Becak (Matabaca) Nurul Hayat Jember. Kedua, untuk mendeskripsikan metode yang digunakan dalam pembinaan keagamaan di Majelis Talim Abang Becak (Matabaca) Nurul Hayat Jember. Ketiga, untuk

${ }^{6}$ https://nurulhayat.org/majelis-talim-abang-becak, (10 November 2019) 


\section{AL-ADABIYAH: Jurnal Pendidikan Agama Islam}

endeskripsikan tujuan pembinaan keagamaan bagi tukang becak melalui Majelis Talim Abang Becak (Matabaca) Nurul Hayat Jember

\section{Tinjauan Literatur}

\section{Pembinaan Keagamaan}

Pembinaan adalah proses perbuatan, pembaharuan, penyempurnaan, usaha, tindakan dan kegiatan yang dilakukan secara terus menerus untuk memperoleh hasil yang lebih baik dari sebelumnya. ${ }^{7}$ Sedangkan keagamaan memiliki arti sesuatu yang berhubungan dengan agama. Menurut Abu Ahmadi dan Noor Salimi ${ }^{8}$, agama adalah risalah yang disampaikan kepada Nabi sebagai petunjuk bagi manusia dan hukum-hukum sempurna untuk dipergunakan manusia dalam menyelenggarakan tata cara hidup yang nyata serta mengatur hubungan dengan dan tanggung jawab kepada Allah, kepada masyarakat serta alam sekitarnya.

Pembinaan keagamaan menurut Ahmad Syafi'i Ma'arif di dalam buku Achmad Mubarok berjudul Psikologi Dakwah ${ }^{9}$ adalah tugas suci yang dibebankan kepada setiap muslim di mana saja ia berada. Kewajiban dakwah, menyerukan dan menyampaikan agama islam kepada masyarakat . fungsi pembinaan keagamaan adalah kegiatan mewujudkan agenda untuk meningkatkan kesejahteraan masyarakat melalui peningkatan kualitas pelayanan dan pemahaman agama serta kehidupan beragama.

Peran pembinaan keagamaan merupakan sebuah kegiatan, ajakan, baik dalam bentuk lisan, tulisan, tingkah laku dan sebagainya, di mana peran tersebut dapat dilakukan secara sadar dan berencana, tentunya dalam upaya mempengaruhi orang lain baik individu, maupun secara kelompok, supaya timbul dalam dirinya sebuah kesadaran, baik dalam sikap penghayatan maupun pengalaman terhadap ajaran agama islam, dan sebagai pesan yang disampaikan kepadanya tanpa ada unsur paksaan dari siapapun.

7 Lina Hadiawati, "Pembinaan Keagamaan Sebagai Upaya Meningkatkan Kesadaran Siswa Melaksanakan Ibadah Shalat”, Jurnal Pendidikan, Vol. 02, No. 01 (2008), 19

8 Abu Ahmadi dan Noor Salim, Dasar-Dasar Pendidikan Agama Islam, (Jakarta: PT Bumi Aksara, 2008), 4

${ }^{9}$ Achmad Mubarok, Psikologi Dakwah, (Jakarta: Prenada Media Group, 2009),vii 


\section{AL-ADABIYAH: Jurnal Pendidikan Agama Islam}

Ahmad Zailani10 berpendapat bahwa pembinaan keagamaan dapat dilakukan dengan pemberian materi yang berkaitan dengan nilai-nilai keagamaan, yakni dilakukan dengan tujuan agar nilai-nilai agama bisa menjadi pedoman dan landasan seseorang dalam bertindak dan menjalani kehidupannya selama di dunia.

Adapun nilai-nilai pembinaan keagamaan dalam hal ini adalah sebagai berikut:

a. Pembinaan Akidah

Ro'is Mahfud ${ }^{11}$ berpendapat bahwa nilai utama dalam kehidupan adalah akidah. Akidah secara etimologi berarti ikatan, simpul dan perjanjian yang kuat dan kokoh. Ikatan dalam pengertian ini merujuk pada makna dasar bahwa sejak azali manusia telah terikat dengan adanya Sang Pencipta, yaitu Allah SWT yang mengatur dan menguasai dirinya. Ikatan kesaksian dan pengakuan manusia terhadap Allah ini tidak ada unsur pemaksaan dari siapapun telah mengucap janji suci ketika maih dalam rahim seorang ibu untuk menerima dan mengakui Allah sebagai tuhannya.

Objek kajian dalam pembahasan akidah menurut Rois Mahfud ${ }^{12}$ meliputi beberapa agenda pembahasan, yaitu pembahasan yang berhubungan dengan beberapa aspek seperti aspek Ilahiyah (ketuhanan), nubuwah, dan ruhaniyah arkanul iman (rukun iman).

Pertama, yaitu pembahasan yang berkaitan dengan aspek ilahiyah meliputi segala yang berkaitan dengan Tuhan, seperti wujud Allah, sifat-sifat Allah, perbuatan-perbuatan dan nama-nama-Nya.

Kedua, yaitu pembahasan tentang kenabian (nubuwah) yang berkaitan dengan Nabi dan Rasul, kitab-kitab Allah yang diturunkan melalui Nabi dan Rasul serta kemukjizatannya.

Ketiga, yaitu aspek ruhaniyah yang membicarakan tentang segala sesutu yang bersifat transendental atau metafisik seperti ruh, malaikat, jin, iblis dan setan.

${ }^{10}$ Ahmad Zailani, Pembinaan Keagamaan Melalui Majelis Taklim Al-Hidayah di Desa Tapung Kecamatan Tandun Kabupaten Rokan Hulu, (Skripsi, UIN SUSKA Riau, Pekanbaru, 2019), 17

${ }^{11}$ Rois Mahfud, AL-ISLAM Pendidikan Agama Islam, (Palangka Raya: Erlangga 2011),

12 Rois Mahfud, AL-ISLAM Pendidikan Agama Islam, (Palangka Raya: Erlangga 2011), 11 
Selain ketiga aspek diatas, aspek keempat yang menjadi lingkup kajian dalam akidah adalah sam'iyah yang membahas tentang dalil-dalil naqli berupa Al-Qur'an dan Sunnah, alam barzakh, akhirat, azab dan kubur.

b. Pembinaan Ibadah

Ibadah secara sederhana diartikan sebagai persembahan, yaitu sembahan manusia kepada Tuhannya yaitu Allah SWT sebagai wujud penghambaan diri kepada Allah SWT. Segala perbuatan apapun yang dilakukan seorang muslim selama itu baik dan diniatkan hanya karena Allah SWT, maka perbuatan tersebut bernilai ibadah di sisi Allah SWT. ${ }^{13}$

Berdasarkan pendapat Ahmad Zailani ${ }^{14}$ ibadah juga merupakan pendekatan diri kepada Allah melalui tata cara yang sudah diatur oleh agama yang bersumber dari dalil naqli Al-Quran dan Sunnah. Ibadah melambangkan hubungan vertikal yang harmonis antara seorang Muslim dengan Tuhannya, karena pada hakikatnya beribadah kepada Allah SWT merupakan tujuan hidup manusia. Hubungan inilah yang akan menjadi daya kontrol yang lekat pada dirinya sehingga terbentuk bangunan kokoh, tangguh dan terkontrol. Dari sinilah akan lahir berbagai bentuk kebajikan yang produktif bagi kehidupan manusia secara umum. Adapun bentuk ibadah ini terbagi atas dua hal yaitu;

Pertama, Ibadah Mahdah yaitu ibadah yang dapat dilihat dari segi format luarnya seperti shalat, puasa, zakat, haji, sedekah, membaca Al-Quran.

Kedua, Ibadah Ghairu Madhah yaitu ibadah yang tidak memiliki format yang baku dalam pelaksanaanya, maka seluruh pekerjaan maupun sikap manusia harus mengetahui motivasinya dalam berbuat. Oleh karena itu, untuk memenuhi misi kemanusiaan sebagai hamba Allah maka selayaknya setiap hamba menjadikan seluruh gerak langkah kehidupannya dijadikan sebagai ibadah.

c. Pembinaan Akhlak

Kata Akhlak secara bahasa merupakan bentuk jamak dari kata khulukun yang berarti budi pekerti, perangai, tabiat, adat, tingkah laku, atau perilaku yang dibuat. Sedangkan secara istilah menurut Abu ahmadi dan Noor Salim ${ }^{15}$ akhlak adalah ilmu yang menentukan batas antara baik dan buruk, baik dan tercela, berupa perkataan maupun perbuatan manusia, lahir dan

\footnotetext{
13 Rois Mahfud, AL-ISLAM Pendidikan Agama Islam, 23

14 Ahmad Zailani, Pembinaan Keagamaan)., 10

15 Abu Ahmadi dan Noor Salim, Dasar-Dasar Pendidikan Agama Islam., 198
} 


\section{AL-ADABIYAH: Jurnal Pendidikan Agama Islam}

batin. Seperti halnya ibadah, akhlak dalam Islam juga mempunyai ruang lingkup, yaitu akhlak manusia terhadap Allah SWT, akhlak manusia terhadap sesama manusia, dan akhlak manusia terhadap lingkungan.

Ahmad Zailani ${ }^{16}$ membagi akhlak menjadi dua yaitu pertama akhlak almahmudah yaitu perangai seseorang yang sangat baik dan terpuji karena dalam dirinya selalu dikendalikan oleh kesadaran kehati-hatian (muraqabah) karena sangat khawatir apabila terlanjur berbuat salah baik kepada Allah maupun kepada manusia. Kedua, akhlak al-mazmumah yaitu perangai seseorang yang buruk (tercela) karena berbuat salah kepada Allah maupun kepada manusia, dan tidak ada jalan lain kecuali segera menyesali perbuatannya dan memohon ampunan kepada kepada Allah atas tindakannya yang menyimpang dari kehendak syariatnya. Karenanya salah satu misi diutusnya Rasulullah saw adalah untuk menyempurnakan akhlak.

Dari uraian diatas maka dapat disimpulkan bahwa pembinaan keagamaan adalah segala usaha yang dilakukan terus menerus untuk memberikan pengajian keagamaan secara rutin dan berkelanjutan untuk menyempurnakan akidah dan pelakasanaan ibadah serta memperbaiki akhlak bagi manusia.

\section{Metode dalam Pembinaan Keagamaan}

Dalam bahasa Arab, metode adalah "thariqah" yang berarti langkah-langkah strategis yang dipersiapkan untuk melakukan suatu pekerjaan. Dengan kata lain, metode merupakan cara yang ditempuh agar hal yang akan disampaikan dapat diterima dengan baik.

Beberapa ahli pendidikan Islam yaitu Abdul Mujib dan Jusuf Mudzakkir ${ }^{17}$ berpendapat bahwa perumusan pengertian metode biasanya disandingkan dengan teknik, yang mana keduanya saling berhubungan. Dalam penggunaan metode pendidikan Islam yang perlu dipahami adalah bagaimana seseorang dapat memahami hakikat metode dalam relevansinya dengan tujuan utama pendidikan Islam, yaitu terbenruknya pribadi yang beriman dan senantiasa mengabdi kepada Allah SWT. Disamping itu juga perlu dipahami beberapa metode instruksional yang aktual dan ditunjukkan dalam Al-Qur'an atau diedukasikan dari Al-Qur'an, atau

16 Ahmad Zailani, Pembinaan Keagamaan)., 10

17 Abdul Mujib dan Jusuf Mudzakkir, Imu Pendidikan Islam, (Jakarta: Kencana Prenada Media, 2010), 165 


\section{AL-ADABIYAH: Jurnal Pendidikan Agama Islam}

dapat memberi motivasi dan disipilin yang dalam istilah Al-Qur'an disebut dengan pemberian anugerah (tsawab) dan hukuman ('iqab).

Agar proses pembinaan berjalan dengan lancar, maka perlu dipilih metode yang tepat dalam menyampaikan materi pembinaan. Pembinaan keagamaan dalam Islam sangat erat kaitannya dengan pendidikan agama Islam, oleh sebab itu metode yang dipakai tidak jauh berbeda dengan metode pendidikan agama Islam.

Diantara metode-metode yang dipakai ialah sebagai berikut:

a. Metode Ceramah

Metode ceramah menurut Maryatin ${ }^{18}$ adalah penerangan dan penuturan secara lisan oleh guru. Guru menerangkan apa yang akan disampaikan dengan lisan. Metode ceramah merupakan metode yang paling banyak dipakai dalam menyampaikan ilmu agama. Hal ini dikarenakan ceramah mudah dilakukan tanpa banyak membutuhkan biaya. Dalam prakteknya, metode ini sering dibarengi dengan tanya jawab. Adapun ciri-ciri ceramah yang baik antara lain sebagai berikut:

1) Memperoleh sambutan/perhatian dari pendengar (audien) sejak kegiatan dimulai.

2) Jelas maksud dan tujuannya serta mudah dipahami mayoritas pendengarnya (bahasa dan istilah yang dipakai tidak bertele-tele).

3) Materi ceramah disesuaikan dengan situasi dan kondisi serta kebutuhan audien (dakwah disampaikan setaraf dengan kemampuan pendengar).

4) Pandangan penceramah tidak mengarah pada satu arah saja, tetapi kepada semua pendengar sehingga ada kontak dengan pendengar.

5) Sebaiknya penceramah dalam menyampaikan ceramah tidak membaca teks, sehingga tidak dianggap bahwa penceramah tidak siap.

6) Menggunakan contoh- contoh yang relevan dengan kejadian yang disampaikan.

7) Dalam menyampaikan pesan harus diorganisir dengan baik.

8) Menghindari hal-hal yang dapat mengganggu jalannya ceramah.

9) Berbicara dengan intonasi yang lembut/disesuaikan dengan kondisi audien.

18 Maryatin, Efektifitas Metode Ceramah Dalam Penyampaian Dakwah Islam: Studi pada Kelompok Pengajian di Perumahan Mojosongo Permai Kabupaten Boyolali, Jurnal Ilmu Dakwah, Vol. 34, No. 1, Januari-Juni 2014 ISSN 1693-8054, 114 


\section{AL-ADABIYAH: Jurnal Pendidikan Agama Islam}

10) Penceramah bersikap ramah, bersahabat, penuh dengan kepercayaan dan menarik para audien.

11)Penceramah berusaha menyimpulkan isi ceramahnya.

12)Isi ceramah menunjukkan edukatif, antara lain dengan ciri; obyektif, rasional, wettenschippelijk (berdasarkan ilmu pengetahuan dan dapat dipertanggung- jawabkan), defensive (mempertahankan kebenaran).

Hal-hal yang juga dapat digunakan untuk menunjang agar ceramah dapat berhasil yakni dengan persiapan perencanaan meliputi;

1) Memilih topik ceramah dengan memperhatikan; tujuan dakwah, kebutuhan massa, situasi dan waktu, lama ceramah, tempat dan media yang dibutuhkan.

2) Menyiapkan outline dan rencana ceramah; muqodimah, isi ceramah, dan penutup.

b. Metode Tanya Jawab

Menurut Ali Mustofa Yakub ${ }^{19}$ metode tanya jawab adalah metode yang dilakukan dengan menggunakan tanya jawab untuk mengetahui ingatan atau pikiran seseorang dalam memahami atau menguasai materi dalam suatu majelis ilmu. Dalam penggunaan metode ini harus digunakan bersama-sama dengan meode lainnya, seperti metode ceramah. Metode tanya jawab ini sifatnya membantu kekurangan yang ada pada metode ceramah.

Metode tanya jawab merupakan salah satu metode yang dilakukan oleh Rasulullah ketika berdakwah. Sebagai contoh, sebuah dialog singkat antara Nabi Muhammad SAW dengan para sahabat tentang al-mufis (orang yang bangkrut). Tanya Nabi, "Tahukan kalian siapa orang yang bangkrut itu?" Para sahabat, karena tidak tahu apa maksud dari Nabi menjawab, "menurut kami orang yang bangkrut itu adalah orang yang tidak mempunyai harta benda". Nabi Muhammad SAW kemudian menjelaskan seraya meluruskan kekeliruan mereka, "orang yang bangkrut diantara umatku adalah orang yang datang pada hari kiamat dengan membawa amalanamalan sholat, puasa dan zakat tetapi ia pernah mencaci orang lain, menuduh zina orang lain, merampas harta orang lain, membunuh dan

${ }^{19}$ Ali Mustafa Yakub, Pendekatan Pendidikan, (Jakarta: Pustaka Firdaus, 2000), 146 


\section{AL-ADABIYAH: Jurnal Pendidikan Agama Islam}

memukul orang. Maka pahala kebajika oramh tersebut akan diberikan sebagai tebusan kepada orang-orang yang didzaliminya itu.

Dengan metode tanya jawab ini, antara ustadz dan jamaah bisa saling bertanya untuk mengembangkan masalah yang ada atau untuk mencari solusi.

Kemudian metode ini juga bisa sebagai salah satu cara yang digunakan dalam berdakwah dengan mempertimbangkan beberapa hal. Menurut M. Basyirudin ${ }^{20}$ metode tanya jawab layak dipakai apabila dilakukan, diantaranya;

1) Sebagai bentuk ujian

2) Sebagai selingan dalam melakukan pembelajaran

3) Untuk memancing jamaah agar perhatian mereka lebih terpusat pada masalah atau materi yang dibahas

4) Untuk mengarahkan proses berfikir.

\section{c. Metode Demonstrasi}

Metode demonstrasi adalah metode yang menggunakan peraga untuk memperjelas suatu pengertian atau menunjukkan suatu proses tertentu.

Metode ini biasanya dipraktikkan oleh da'i atau ustadz terlebih dulu untuk diikuti dan ditiru jamaah agar pemahamannya semakin luas dan memperbanyak pengalaman dan mengurangi kesalahpahaman. ${ }^{21}$

Dalam metode ini juga bisa dilakukan dengan kegiatan karyawisata religi (al-rihlah al-ilmiyah) yaitu dengan membawa jamaah pada objek yang akan dipelajari langsung. Sebagai contoh dengan berkunjung ziarah ke makam para wali Allah kemudian melakukan doa dan mengaji bersama di sekitar makam.

\section{Tujuan Pembinaan Keagamaan}

Pada dasarnya pembinaan keagamaan dilakukan untuk merubah tingkah laku orang-orang yang mengikuti proses pembinaan. Perubahan tingkah laku yang dimaksud yaitu berupa bertambahnya pengetahuan, keahlian, keterampilan, perubahan sikap dan perilaku menjadi lebih baik.

${ }^{20}$ M. Basyiruddin, Metodologi Pembelajaran Agama Islam, (Jakarta: Ciputat Pers, 2002), 43

21 Abdul Mujib dan Jusuf Mudzakkir, Imu Pendidikan Islam, 197 


\section{AL-ADABIYAH: Jurnal Pendidikan Agama Islam}

Seperti halnya yang telah dijelaskan oleh Zakiah Darajat22 tujuan pembinaan keagamaan itu memiliki tiga aspek yaitu iman, ilmu dan amal yang pada dasarnya berisi:

1) Menumbuh dan mengembamgkan serta membentuk sikap positif dan disiplin serta rasa cinta terhadap agama dalam berbagai kehidupan yang nantinya diharapkan bisa menjadi hamba yang bertakwa kepada Allah SWT dan taat terhadap Rasul-Nya

2) Mengembangkan pengetahuan agama dalam pembentukan insan kamil yang berakhlak mulia, bertakwa kepada Allah SWT, sesuai dengan ajaran agama Islam dan mempunyai keyakinan yang kokoh kepada Allah SWT.

3) Menumbuhkan dan membina keterampilan beragama di berbagai kehidupan serta dapat memahami dan menghayati ajaran agama Islam secara mendalam dan menyeluruh, sehingga dapat dijadikan sebagai pedoman hidup, baik dalam hubungannya dengan Allah SWT melalui ibadah dan dalam hubungannya dengan sesama manusia yang tercermin pada akhlaknya serta hubungan dirinya dengan alam sekitar.

Beberapa ahli lain juga membagi tujuan pembinaan keagamaan menjadi dua, yaitu tujuan yang berorientasi pada kehidupan dunia dan pada kehidupan akhirat, diantaranya:

1) Tujuan yang berorientasi pada kehidupan dunia yaitu mengutamakan pada upaya untuk mewujudkan kehidupan sejahtera di dunia dan kemanfaatannya. Menurut padangan Islam, pada hakikatnya kehidupan duniawi mengandung makna ukhrawi karena dengan mengamalkan ilmu dan teknologi manusia mampu berbuat lebih banyak amal-amal kebajikan di dunia dibanding dengan orang-orang yang tidak berilmu pengetahuan dan teknologi. Amal baik itulah yang menjadi faktor penentu bagi hidup bahagianya di akhirat. ${ }^{23}$

2) Tujuan yang berorientasi pada kehidupan akhirat yaitu tujuan yang difokuskan kepada pembentukan pribadiseorang muslim yang sanggup melaksanakan syariat Islam melalui proses pendidikan spiritual menuju makrifat kepada Allah. ${ }^{24}$

${ }^{22}$ Zakiah Daradjat, Imu Pendidikan Islam, (Jakarta: Bumi Aksara, 2006), 90

${ }^{23}$ M. Arifin, Imu Pendidikan Islam, (Jakarta: Bumi Aksara, 2003), 59

${ }^{24}$ Nur Hidayati, Ilmu Pendidikan Islam, (Bandung: Pustaka Setia, 1999), 61 


\section{AL-ADABIYAH: Jurnal Pendidikan Agama Islam}

\section{Metode}

Pendekatan yang digunakan dalam penelitian ini adalah pendekatan kualitatif. Penelitian kualitatif menurut Lexy $\mathrm{J}$ Moleong ${ }^{25}$ adalah penelitian yang bermaksud untuk memahami fenomena yang dialami oleh subjek peneliti, misalnya perilaku, tujuan, motivasi, tindakan dan sebagainya dengan cara mendeskripsikan dalam bentuk uraian kata-kata dan bahasa pada suatu konteks khusus dengan pemanfaatan beberapa metode ilmiah. Jenis penelitian yang digunakan dalam penelitian ini adalah penelitian lapanagan (Field Research), yaitu suatu metode penelitian yang digunakan untuk mengumpulkan data kualititafif, dalam penelitian ini data diperoleh dari lapangan secara langsung dan dari sumbernya. ${ }^{26}$

Teknik pengumpulan data yang dilakukan dalam penelitian ini adalah sebagai berikut:

1. Observasi

Dalam penlitian ini peneliti akan menggunakan jenis observasi nonpasrtisipan dalam mengumpulkan datanya, karena peneliti hanya sebagai pengamat saja di lapangan.

2. Wawancara

Jenis wawancara yang akan digunakan dalam penelitian ini ialah wawancara semi-struktur, yaitu wawancara yang pelaksanaannya lebih bebas bila dibandingkan dengan wawancara terstruktur.

3. Studi Dokumen

Dokumen merupakan catatan peristiwa yang sudah berlalu. Dokumen bisa berupa tulisan, gambar, atau karya-karya monumental dari seseorang.

Adapun teknik analisis data yang digunakan pada penelitian ini adalah analisis kualitatif model Miles, Huberman dan Saldana ${ }^{27}$ yaitu:

a. Kondensasi Data (Data Condensation)

Kondensasi data dilakukan oleh peneliti dengan proses menyeleksi data yang diperoleh selama penelitian di Matabaca Nurul Hayat Jember, kemudian menfokuskan dan menyederhanakan data yang diperoleh tersebut 2017), 6

${ }^{25}$ Lexy J Meloeng, Metode Penelitian Kualitatif, (Bandung: PT Remaja Rosda Karya,

26 Lexy J Meloeng, Metode Penelitian Kualitatif, 26

27 Matthew B. Milles, A. Michael Huberman, dan Jhonny Saldana, Qualitative Data Analysis, A Methods Sourcebook, (California: SAGE Publication, 2014), 31 
sesuai dengan data yang dibutuhkan pada fokus penelitian untuk disajikan secara lebih rinci.

b. Penyajian Data (Data Display)

Penyajian data dilakukan peneliti dengan penyatuan informasi dan data-data yang diperoleh untuk penyimpulan dan penulisan ke dalam hasil penelitian. Dalam penyajian data ini peneliti bisa lebih memahami untuk menganilis data yang akan disajikan secara lebih mendalam.

c. Penarikan Kesimpulan atau Verifikasi (Conclusion Drawing/ Verification)

Penarikan kesimpulan adalah tahap akhir yang dilakukan peneliti dalam proses analisis data. Pada bagian ini peneliti menyimpulkan data-data yang telah diperoleh selama penelitian hingga penulisan dan penyajian data. Melalui kegiatan ini peneliti mampu mencari makna dari data yang telah dikumpulkan dengan mencari persamaan atau perbedaan. Penarikan kesimpulan dilakukan dengan memandingkan kesesuaian pernyataan dari subyek penelitian dengan makna yang terdapat pada konsep-konsep dan teori dasar dalam penelitian ini.

\section{Hasil dan Diskusi}

Pembinaan Keagamaan dalam Kehidupan Tukang Becak Melalui

\section{Majelis Taklim Abang Becak (MATABACA) Nurul Hayat Jember}

Yayasan Nurul Hayat merupakan yayasan yang bergerak dalan bidang sosial dan dakwah. Yayasan ini berpusat di kota Surabaya dan memiliki cabang yang sudah tersebar di beberapa kota lainnya. Salah satunya adalah di kota Jember, yang terletak di Jl. Imam Bonjol No.7 Kav.5 kecamatan Kaliwates kabupaten Jember.

Yayasan Nurul Hayat Jember didirikan sejak tahun 2014. Yayasan Nurul Hayat ini dicita-citakan untuk menjadi lembaga milik umat yang mandiri. Lembaga milik umat ini artinya adalah lembaga yang dipercaya oleh umat karena mengedepankan transparansi dan akuntabilitas dalam mengelola dana amanah dari umat. Sedangkan lembaga yang mandiri artinya adalah semua biaya operasional termasuk gaji karyawan dipenuhi secara mandiri dari hasil unit usaha dan jasa layanan aqiqoh yang berkembang pesat di berbagai daerah. Sehingga, donasi umat yang 


\section{AL-ADABIYAH: Jurnal Pendidikan Agama Islam}

berupa zakat, infaq dan shodaqoh 100\% disalurkan untuk mendukung progam-progam layanan sosial, pemberdayaan dan dakwah Nurul Hayat.

Yayasan Nurul Hayat Jember memiliki beberapa layanan sosial, diantaranya ${ }^{28}$ :

a. Pesantren Binaan Nurul Hayat Jember, bertempat di Karanganyar Ambulu, ada 73 anak yang dibiayai Nurul Hayat Jember dan masuk kategori Yatim Dhu'afa. Para santri di pesantren ini wajib menghafal Al-Qur'an.

b. SAYANG (Sahabat Yatim Cemerlang), sebanyak 450 anak Yatim Dhu'afa mendapat beasiswa dari Nurul Hayat Jember setiap bulan.

c. Pembinaan Yatim, ada 8 titik/wilayah pembinaan untuk anak Yatim Dhu'afa dengan mencari bakat. Binaan tersebut diantaranya adalah, Latihan Qari', Al-Banjari, Kursus Bahasa Arab, Kursus Bahasa Inggris dan Kursus Komputer.

d. SAJADA (Santunan Janda Tua Dhuafa), ada 125 janda tua dhuafa yang setiap bulannya mendapat sembako dari Nurul Hayat Jember

e. Kajian Ahad Dhuha, kajian keagamaan untuk umum yang dilaksanakan setiap satu bulan sekali.

f. TAFAQUR (Tanda Cinta Untuk Penghaf Al-Qur'an), kegiatan yang dikhususkan untuk para penghafal al-Qur'an. Setiap satu bulan sekali mengadakan khatmil Qur'an di kantor Yayasan Nurul Hayat, kecuali ada permintaan di rumah jamaah masing-masing.

g. MATABACA (Majelis Taklim Abang Becak) kegiatan pembinaan keagamaan yang dilakukan khusus untuk para abang becak yang dilaksanakan seiap satu bulan sekali yang tersebar di 3 wilayah yaitu, Kepatihan, Patrang dan Tegal Besar.

h. Kajian Bunda Yatim, yaitu majelis taklim khusus ibu-ibu dari anak yatim yang tersebar di 3 daerah di Jember yaitu Jelbuk, Jenggawah dan Wuluhan.

28 Bapak Latif, wawancara dan dokumentasi, Jember, 12 Maret 2020 
i. SAHABAT (Santunan Kesehatan dan Berobat), yayasan Nurul Hayat membantu ratusan faqir miskin untuk mendapat pelayanan kesehatan gratis.

j. DANSOS (Dana Sosial) yaitu bantuan untuk orang-orang yang sangat mmbutuhkan, seperti bantuan menebus obat bagi pasien yang tidak mampu membeli/menebus obatnya sendiri, biaya menebus ijazah karena punya tunggakan hutang di sekolah, dll.

k. SIGAP (Aksi Tanggap Bencana) yaitu kegiatan yang dilakukan setiap ada bencana di Jember maupun daerah sekitar Jember dengan memberikan bantuan sosial berupa makanan dan obat-obatan, dll.

1. GENPRES (Generasi Prestasi) yaitu beasiswa untuk anak Yatim Dhuafa yang berprestasi.

m. Warung Berkah, setiap Jum'at Nurul Hayat Jember membuka warung berkah di 5 titik/wilayah, yaitu depan RS Soebandi, Pasar Tanjung, Pasar Gebang, Pasar Mangli dan Pasar Jenggawah. Setiap hari Jum'at memberikan makan gratis bagi yang tidak mampu.

n. Rombong Berkah, yaitu bantuan untuk keluarga yang mau membuka usaha namun tidak ada rombong atau yang sudah rusak rombongnya.

o. Pilar Mandiri (Penciptaan Lapagan Kerja Mandiri), berupa bantua modal usaha tanpa bunga dan pendampingan kewirausahaan bagi anggot binaan KBJ (Koperasi Berani Jujur), Rombong Berkah, dll.

p. IBUQU (Intensif Bulanan Guru Al-Qur'an), berupa pemberian intensif dan pendampingan usaha ekonomi kreatif bagi guru AlQur'an.

q. Sarpras TPQ (Sarana dan Pra Sarana TPQ), kurang lebih ada 66 TPQ di Jember yang mendapat bantuan sarana dan pra sarana dari Nurul Hayat Jember

r. Surga Desa (Sumur untuk Warga Desa), yaiitu pembangunan ataupun pengeboran sumur di tempat-tempat yang kesulitan air. 
Dari sekian banyak program sosial dan pemberdayaan umat yang ada di Yayasan Nurul Hayat Jember, yang menjadi fokus kajian dalam penelitian ini adalah pelakasanaan pembinaan keagamaan bagi kehidupan tukang becak melalui Matabaca Nurul Hayat Jember.

Pembinaan kagamaan yang ada di Matabaca Nurul Hayat Jember dimaksudkan agar nilai-nilai agama Islam bisa menjadi pedoman dan landasan bagi para abang becak dalam bertindak dan menjalani kehidupannya selama di dunia. Adapun pembinaan keagamaan yang diberikan di Matabaca Nurul Hayat Jember adalah sebagai berikut:

a. Pembinaan Akidah

Pembinaan nilai akidah yang ada di majelis taklim ini adalah dengan memberikan materi materi yang berkaitan dengan akidah Islam seperti yang telah diberikan oleh ustadz Abdullah Muzakka tentang iman kepada takdir Allah, dan yang disampaikan oleh Ustadz Rofi'i Baidlawi yaitu pendekatan tauhid tentang kesempurnaan akal manusia yang digunakan untuk bertafaqur atas kekuasaan Allah agar dapat meningkatkan keimanan dan ketaqwaan kepada Allah SWT.

Hasil temuan ini sesuai dengan teori yang dijelaskan oleh Ro'is Mahfud tentang objek kajian dalam akidah yang meliputi pembahasan tentang aspek Ilahiyah (ketuhanan), nubuwah, dan ruhaniyah arkanul iman (rukun iman). ${ }^{29}$

Selain itu, dalam pembinaan nilai akidah, Matabaca juga berupaya memberikan materi-materi kajian yang berkaitan dengan nilai akidah Islam yang sangat ringan dan mudah dipahami oleh para jamaah Matabaca.

Penyampaian materi yang terkait dengan akidah di majelis taklim ini tidak hanya secara tekstual seperti yang ada di bukubuku maupun kitab pada umunya. Akan tetapi kami juga

${ }^{29}$ Rois Mahfud, AL-ISLAM), 11 
berusaha menjelaskan materi kontkstual yang dikaitkan dengan pengamalan dalam kehidupan sehari-hari. ${ }^{30}$

Dari hasil beberapa hasil wawancara dengan Ustadz Abdullah Muzakka dan Ustadz Rofi'i Baidlawi serta dikuatkan dengan observasi langsung yang dilakukan peneliti diatas, maka dapat disimpulkan bahwa pembinaan akidah yang ada di majelis taklim ini tidak hanya memberikan materi akidah Islam secara kontekstual saja, akan tetapi juga mengaitkan dengan situasi dan kondisi kekinian yang ada, sehingga para jamaah tidak hanya sekedar meyakini saja tetapi juga bisa mengamalkan nilai-niai akidah di dalam kehidupan sehari-hari mereka.

Sebagaimmana yang telah diketahui berdasarkan pendapat Ahmad Zailani ${ }^{31}$ yang menjelaskan bahwa akidah tidaklah cukup dengan sekedar keyakinan atau pengakuan lisan saja, akan tetapi ia harus dibuktikan dengan amal. Dengan demikian ada 3 unsur yang harus dipenuhi agar iman itu sempurna. Unsur hati sebagai tempat keyakinan, unsur lisan sebagai tempat pengakuan dan unsur amal sebagai tempat pembuktian.

b. Pembinaan Ibadah

Pembinaan ibadah yang ada di Matabaca ini memiliki peran yang sangat penting. Dengan diberikan materi tentang ibadah, para jamaah dapat memahami serta menerapkan langsung dalam kehidupan mereka. Sehingga, meskipun pekerjaan sebagai tukang becak yang setiap harinya lebih banyak menggunakan waktunya untuk bekerja tidak menjadi halangan bagi mereka untuk tetap melakukan ibadah sebagaimana kewajiban seorang hamba kepada Tuhannya. Baik itu ibadah wajib maupun ibadah sunnah.

30 Ustadz Abdullah Muzakka, diwawancara oleh penulis, Jember, 20 Maret 2020

${ }^{31}$ Ahmad Zailani, Pembinaan Keagamaan, 9 
Ustadz/pemateri di majelis taklim ini tidak hanya memberikan materi tentang ibadah-ibadah mahdah saja, namun juga sering memberikan materi-materi tentang ibadah ghairu mahdah.

Hal tersebut sesuai dengan pendapat yang dijelaskan oleh Ahmad Zailani ${ }^{32}$ bahwa ibadah merupakan pendekatan diri kepada Allah melalui tata cara yang sudah diatur oleh agama yang bersumber dari dalil naqli Al-Quran dan Sunnah. Adapun bentuk ibadah ini terbagi atas dua hal yaitu ibadah mahdah yaitu ibadah yang dapat dilihat dari segi format luarnya seperti shalat, puasa, zakat, haji, sedekah, membaca Al-Quran. Dan yang kedua adalah ibadah ghairu madhah yaitu ibadah yang tidak memiliki format yang baku dalam pelaksanaanya, maka seluruh pekerjaan maupun sikap manusia harus mengetahui motivasinya dalam berbuat. Oleh karena itu, untuk memenuhi misi kemanusiaan sebagai hamba Allah maka selayaknya setiap hamba menjadikan seluruh gerak langkah kehidupannya dijadikan sebagai ibadah.

Pemberian materi ibadah yang termasuk dalam materi ibadah mahdah seperti thaharah, sholat, puasa, zakat, dll sudah tuntas dibahas oleh ustadz Baidlawi. Dan untuk saat ini ustadz lebih banyak memberikan materi tentang ibadah ghairu mahdah dan ibadah sunnah lainnya. Dalam penyampaiannya ustadz selalu mengaitkan dengan kehidupan dan pekerjaan jamaah sebagai abang becak. Beliau memberikan penjelasan tentang bagaimanapun dan apapun pekerjaan yang dilakukan jika diniatkan baik karena Allah, maka akan bernilai ibadah dan mendapat pahala dari Allah SWT. Sehingga para jamaah juga bisa lebih mudah dalam memahami dan mengamalakan dalam kehidupan sehar-harinya. ${ }^{33}$

Selain itu materi-materi tentang ibadah yang diberikan di majelis taklim ini juga disesuaikan dengan kejadian ataupun momen yang ada pada saat bulan tersebut. Seperti pada saat memasuki bulan Muharram maka materi ibadah yang diberikan adalah tentang ibadah-ibadah yang dapat dilakukan saat bulan Muharram.

32 Ahmad Zailani, Pembinaan Keagamaan., 10

33 Bapak Ridwan, diwawancara oleh penulis, Jember, 04 Februari 2020 
Hal tersebut sesuai dengan hasil observasi peneliti pada tanggal 21 Februari 2020 dan pada 03 Maret 2020 di Matabaca wilayah Patrang dan Matabaca wilayah Kepatihan. Pada saat itu pematerinya adalah Ustadz Kholilur Rohman. Ustadz Kholil menjelaskan materi tentang amalan berdzikir dan beristighfar kepada Allah serta ibadah puasa sunnah pada bulan Rajab. Karena pada bulan tersebut sedang memasuki bulan Rajab.

Temuan ini selaras dengan pendapat dari Maryatin di dalam Jurnal Ilmu Dakwah yang menjelaskan bahwa salah satu ciri-ciri dakwah yang baik adalah materi yang diberikan disesuaikan dengan situasi dan kondisi serta kebutuhan audien. ${ }^{34}$

c. Pembinaan Akhlak

Penyampaian materi-materi yang berkaitan dengan Akhlak juga disampaikan oleh para Ustadz yang mengisi kajian di majelis taklim ini. Akhlak dalam Islam dibagi menjadi dua yaitu akhlak kepada Allah dan akhlak kepada manusia.

Pembinaan akhlak yang ada di Matabaca adalah dengan memberikan penjelasan tentang bagaimana akhlak yang baik yang seharusnya dilakukan oleh manusia, yaitu akhlak kepada Allah dan akhlak kepada sesama manusia ataupun makhluk Allah yang lain. Materi yang diberikan oleh ustadz diantaranya adalah tentang akhlak kepada sesama manusia. Seperti yang telah dijelaskan oleh ustadz Abdullah Muzakka bahwa beliau memberikan pemahaman kepada jamaah agar senantiasa memiliki akhlak yg baik dan mampu memberikan kenyaman kepada siapapun yang ada di sekitar mereka. Sedangkan Akhlak kepada Allah diantaranya adalah dengan senantiasa beribadah dan bertaubat kepada Allah.

Hasil temuan diatas selaras dengan teori dari Abu ahmadi dan Noor Salim35 yang menjelaskan bahwa akhlak dalam Islam mempunyai ruang lingkup, yaitu akhlak manusia kepada terhadap 
Allah SWT, akhlak manusia terhadap sesama manusia, dan akhlak manusia terhadap lingkungan.

Metode Dalam Pembinaan Keagamaan Bagi Tukang Becak Melalui Majelis Talim Abang Becak (Matabaca) Nurul Hayat Jember

Pada dasarnya pembinaan keagamaan sama dengan pendidikan agama pada umumnya. Sehingga dalam menyampaikan materi juga memerlukan metode agar lebih mudah dipahami oleh para jamaah. Di Matabaca para ustadz juga menggunakan berbagai macam metode dalam menyampaiakan isi kajiannya, namun metode yang digunakan ini disesuaikan dengan kondisi para jamaah.

Adapun metode pembinaan keagamaan yang digunakan oleh para ustadz di Matabaca adalah sebagai berikut:

a. Metode Ceramah

Metode yang sering digunakan di Matabaca ini adalah metode ceramah. Karena metode ini sangat sederhana dan merupakan metode yang sangat akrab dengan lingkungan majelis taklim pada umumnya.

Dari pernyataan yang telah peneliti dapatkan dari hasil wawancara diatas, maka hal tersebut juga diperkuat dengan hasil observasi yang dilakukan oleh peneliti. Benar bahwa ustadz yang mengisi kajian Matabaca menggunakan metode ceramah. Ustadz menyampaikan materi seperti biasa dan jamaah memeprhatikan dan mendengarkan apa yang disampakan oleh ustadz. Ustadz juga menerangkan materi lebih luas menggunakan bahasa madura agar mudah dipahami oleh jamaah, karena mayoritas jamaah Matabaca juga berbahasa madura.

Berdasarkan hasil wawancara dan observasi diatas maka dapat disimpulkan bahwa metode yang lebih sering dipakai oleh ustadz/pemateri saat menyampaikan isi kajiannya di Matabaca menggunakan metode ceramah. Dan untuk mempermudah jamaah 
dalam memahami materi, ustadz juga menjelaskan dengan menggunakan bahasa Madura.

Temuan tersebut sesuai dengan teori dari Jurnal Ilmu Dakwah yang ditulis oleh Maryatin ${ }^{36}$ bahwa ciri-ciri ceramah yang baik diantaranya adalah materi ceramah disesuaikan dengan situasi dan kondisi serta kebutuhan audien (dakwah disampaikan setaraf dengan kemampuan pendengar).

b. Metode Tanya Jawab

Selain menggunakan metode ceramah, ustadz/pemateri di Matabaca ini juga menggunakan metode tanya jawab, namun metode tanya jawab disini tidak terlalu sering digunakan dan hanya dilakukan oleh ustadz kepada jamaah saja, untuk mngetahui apakah yang disampaikan oleh ustadz sudah dipahami jamaah atau belum.

Berdasarkan hasil observasi lapangan yang dilakukan peneliti selama mengikuti kajian Matabaca di wilayah Kepatihan dan di wilayah Patrang, benar bahwa pelaksanaan Matabaca menggunakan metode ceramah dan tanya jawab. Ustadz memberikan materi kajian menggunakan bahasa Indonesia, namun penjelesan secara luas menggunakan bahasa Madura. Jamaah mendengarkan dengan baik, jika ada jamaah yang tampak belum memahami materi yang disampaikan maka ustadz bertanya kepada jamaah tersebut. Dan apabila jamaah belum paham maka ustadz menjelaskan kembali materinya.

Temuan tersebut juga sesuai dengan teori Menurut $M$. Basyirudin ${ }^{37}$ metode tanya jawab layak dipakai apabila dilakukan, diantaranya adalah sebagai bentuk ujian, sebagai selingan dalam melakukan pembelajaran, untuk memancing jamaah agar perhatian

37 M. Basyiruddin, Metodologi Pembelajaran Agama Islam, 43 
mereka lebih terpusat pada masalah atau materi yang dibahas dan untuk mengarahkan proses berfikir.

c. Metode Demonstrasi

Metode demonstrasi yang digunakan di Matabaca disesuaikan dengan materi yang disampaikan. Penyampaian materi yang sering menggunakan metode demonstrasi adalah materi-materi ibadah. Seperti halnya materi tentang wudhu, tayamum, sholat, perawatan jenazah, dan sebagainya. Ustadz menjelaskan materi disertai dengan praktek langsung di depan jamaah kemudian jamaah memperhatikan dan mengikuti.

Dari hasil wawancara dengan narasumber diatas, maka dapat dipahami bahwa penggunaan metode demonstrasi di majelis taklim ini lebih sering dilakukan ketika materi-materi yang berkaitan dengan ibadah. Ustadz menjelaskan kemudian mempraktekkan di depan para jamaah, namun tanpa menggunakan alat peraga, hanya dengan gerakan-gerakan saja. Meskipun demikian, para jamaah tidak sulit dalam memahaminya karena materi yang dijelaskan sangat ringan dan biasa dilakukan sehari-hari. Jadi meskipun ustadz praktek hanya dengan gerakan-gerakan saja tanpa alat, para jamaah tetap bisa memahaminya dengan baik.

Penggunaan metode demonstrasi di Matabaca terkadang juga sesuai dengan permintaan dari pihak Nurul Hayat. Selain praktek bersuci dari hadas yang telah dikemukakan oleh Ustadz kholil diatas. Majelis taklim ini juga memberikan materi yang disertai praktek sesuai dengan momen yang ada. Sebagai contoh bahwa beberapa bulan yang lalu Matabaca mengadakan wisata religi untuk para jamaahnya yaitu berupa ziarah wali. Sehingga pihak Nurul Hayat juga meminta para ustadz untuk memberikan pemahaman kepada jamaah tentang sholat jamak qhosor dan mempraktekkan tentang tata caranya, dengan tujuan 
agar pada saat di perjalanan para jamaah bisa melakukan sholat jamak qhosor dengan baik dan benar sesuai syariat Islam.

Temuan tersebut sesuai dengan teori yang menjelaskan bahawa metode demonstrasi biasanya dipraktikkan oleh da'i atau ustadz terlebih dulu untuk diikuti dan ditiru jamaah agar pemahamannya semakin luas dan memperbanyak pengalaman dan mengurangi kesalahpahaman. ${ }^{38}$

\section{Tujuan Pembinaan Keagamaan Bagi Tukang Becak Melalui Majelis Taklim Abang Becak (Matabaca) Nurul Hayat Jember}

Pembinaan keagamaan yang ada di Matabaca memiliki tujuan untuk merubah sikap dan tingkah laku serta kehidupan beragama para jamaahnya menjadi lebih baik.

Sesuai dengan problematika dan permasalahan yang yang telah dijelaskan di bab awal, maka Matabaca Nurul Hayat Jember berusaha untuk membantu dan membina kehidupan mereka menjadi lebih baik. Sebagaimana yang telah disampaikan oleh Bapak bahwa prinsip yayasan Nurul Hayat untuk semua anggota binaanya yang mayoritas adalah para Yatim dan Dhuafa yaitu "meskipun miskin di dunia tapi jangan sampai miskin di akhirat". Sehingga dengan adanya program-program dakwah yang ada di Nurul Hayat ini terutama program Matabaca adalah untuk memperbaiki kehidupan para jamaahnya. Baik dalam kehidupan di dunia maupun kebaikan di akhirat mereka. Yayasan Nurul Hayat memberikan bantuan dan santunan uang serta sembako guna memberdayakan ekonomi para jamaahnya.

Hasil temuan melalui wawancra diatas sesuai dengan teori yang dijelaskan oleh Helmawati bahwa salah satu fungsi majelis taklim adalah fungsi ekonomi, yakni sebagai sarana tempat pembinaan dan pemberdayaan ekonomi jamaahnya. ${ }^{39}$

Selain itu, tujuan utama adanya pembinaan keagamaan melalui majelis taklim ini adalah untuk merubah yang belum baik menjadi baik,

${ }^{38}$ Abdul Mujib dan Jusuf Mudzakkir, Ilmu Pendidikan Islam, 197

${ }^{39}$ Helmawati, Pendidikan Nasional Dan Optimalisasi Majelis Ta'lim, 91 


\section{AL-ADABIYAH: Jurnal Pendidikan Agama Islam}

yang sudah baik menjadi lebih baik, dan bisa memberi teladan yang baik juga untuk orang lain di sekitarnya. Dengan mengikuti majelis taklim ini ada jamaah Matabaca Nurul Hayat yang telah memiliki kebiasaan baik setelah ikut pembinaan disini. Karena di majelis taklim ini sering dijelaskan terkait fadhilah-fadhilah membaca Al-Quran, menjaga wudhu, berdzikir, sholawat, dll. Akhirnya, jamaah pun mengamalkannya dalam kehidupan sehari-hari, ketika ada waktu luang disela-sela pekerjaan mereka, mereka menggunakan waktunya untuk hal-hal yang bermanfaat dan bernilai pahala, seperti membaca Al-Qur'an, berdzikir, bershalawat, dan lain sebagainya.

Berdasarkan hasil penelitian yang diperoleh tersebut, tujuan utama adanya pembinaan keagamaan melalui Matabaca adalah untuk merubah yang belum baik menjadi baik, yang sudah baik menjadi lebih baik, dan bisa memberi teladan yang baik juga untuk orang lain di sekitarnya. Para jamaah Matabaca yang mengikuti majelis taklim ini adalah para orang dewasa dan bahkan lanjut usia yang memang sudah tidak mampu lagi menimba ilmu melalui pendidikan formal, sehingga alternatif yang mudah untuk mendapatkan ilmu agama adalah melalui majelis taklim ini.

Temuan diatas juga selaras dengan teori yang telah dijelaskan oleh Zakiah Darajat 40 bahwa tujuan pembinaan keagamaan adalah untuk Mengembangkan pengetahuan agama dalam pembentukan insan kamil yang berakhlak mulia, bertakwa kepada Allah SWT, sesuai dengan ajaran agama Islam dan mempunyai keyakinan yang kokoh kepada Allah SWT.

Tujuan lain dari pembinaan keagamaan yang disampaikan oleh para jamaah Matabaca ini adalah untuk menumbuh dan mengembangkan sikap disiplin terhadap perintah agama. Seperti sholat yang pada dasarnya adalah wajib hukumnya, sehingga semua muslim diwajibkan untuk melaksanakannya. Dimanapun mereka berada dan bagaimanapun keadaannya harus selalu melaksanakan kewajiban sebagai seorang Muslim.

40 Zakiah Daradjat, Imu Pendidikan Islam, 90 


\section{AL-ADABIYAH: Jurnal Pendidikan Agama Islam}

Temuan ini juga selaras dengan teori yang telah dijelaskan oleh Zakiah Darajat 41 bahwa tujuan pembinaan keagamaan itu adalah untuk menumbuh dan mengembamgkan serta membentuk sikap positif dan disiplin serta rasa cinta terhadap agama dalam berbagai kehidupan yang nantinya diharapkan bisa menjadi hamba yang bertakwa kepada Allah SWT dan taat terhadap Rasul-Nya.

Terkait tujuan pembinaan keagamaan di Matabaca yang berhubungan dengan lingkungan sosialnya yaitu di masyarakat, juga telah disampaikan oleh Ustadz Abdullah Muzakka, beliau berpendapat bahwa tujuan lain dari adanya pembinaan keagamaan melalui Matabaca adalah memberikan ruang kepada para tukang becak agar diakui keberadannya oleh masyarakat sekitar. Karena tidak sedikit masyarakat yang memandang para tukang becak ini hanya dengan sebelah mata saja. Sehingga dengan diberikan ruang berupa majelis taklim ini, para tukang becak bisa diakui keberadannya, karena majelis takilm ini merupakan ruang terhormat yang didalamnya terdapat berbagai macam kegiatan positif untuk para jamaahnya antara lain adalah mengembangkan wacana keilmuan keagamaan bersama dengan ustadz-ustadz yang sudah terpercaya.

Sesuai dengan hasil wawancara dengan salah satu ustadz yang mengisi kajian di Matabaca ini yaitu tujuan lain dari adanya pembinaan keagamaan melalui Matabaca adalah memberikan ruang kepada para tukang becak agar diakui keberadannya oleh masyarakat sekitar. Karena tidak sedikit masyarakat yang memandang para tukang becak ini hanya dengan sebelah mata saja. Sehingga dengan diberikan ruang berupa majelis taklim ini, para tukang becak bisa diakui keberadannya, karena majelis takilm ini merupakan ruang terhormat yang didalamnya terdapat berbagai macam kegiatan positif untuk para jamaahnya antara lain adalah mengembangkan wacana keilmuan keagamaan bersama dengan ustadzustadz yang sudah terpercaya.

${ }^{41}$ Zakiah Daradjat, Imu Pendidikan Islam, 90 


\section{AL-ADABIYAH: Jurnal Pendidikan Agama Islam}

Temuan ini senada dengan teori menurut Helmawati yang menjelasakan tentang fungsi majelis taklim yaitu fungsi sosial yang menjadi sarana silaturahmi, menyampaikan gagasan, dan sekaligus sarana dialog antar ulama, umara dan ummat. ${ }^{42}$

Dari hasil wawancara dengan beberapa narasumber dan observasi langsung oleh peneliti, maka dapat disimpulkan bahwa tujuan pembinaan keagamaan melalui Matabaca adalah sebagai berikut:

a. Untuk memberdayakan ekonomi para jamaah Matabaca

b. Untuk mengembangkan pengetahuan agama dan merubah sikap dan tingkah laku serta kehidupan beragama para jamaahnya menjadi lebih baik.

c. Untuk menumbuh dan mengembangkan sikap positif dan disiplin terhadap agama

d. Untuk memberikan ruang kepada jamaah agar diakui keberadaanya oleh masyarakat melalui majelis taklim yang mampu memberikan kegiatan positif di dalamnya.

\section{Kesimpulan}

1. Pembinaan keagamaan dalam kehidupan bagi tukang becak melalui majelis taklim abang becak (Matabaca) Nurul Hayat Jember terdiri atas pembinaan akidah, pembinaan ibadah dan pembinaan akhlak. Penyampaian materi tersebut disampaikan secara luas dan menyeluruh, para ustadz juga mengaitkan dengan kehidupan sehari-hari sehingga para jamaah tidak hanya memahami secara tekstualnya saja akan tetapi juga mampu menerapkannya dalam kehidupan mereka.

2. Metode yang digunakan dalam pembinaan keagamaan bagi tukang becak melalui majelis taklim abang becak (Matabaca) Nurul Hayat Jember yaitu metode ceramah, metode tanya jawab dan metode demonstrasi. Penggunaan metode tersebut disesuaikan dengan jenis materi yang disampaikan saat kajian.

42 Helmawati, Pendidikan Nasional Dan Optimalisasi Majelis Ta'lim, 91 
3. Tujuan pembinaan keagamaan bagi tukang becak melalui majelis taklim abang becak (Matabaca) Nurul Hayat Jember yaitu (1) Untuk mmberdayakan ekonomi para jamaah Matabaca. (2) Untuk mengembangkan pengetahuan agama dan merubah sikap dan tingkah laku serta kehidupan beragama para jamaahnya menjadi lebih baik. (3) Untuk menumbuh dan mengembangkan sikap positif dan disiplin terhadap agama. (4) Untuk memberikan ruang kepada jamaah agar diakui keberadaanya oleh masyarakat melalui majelis taklim yang mampu memberikan kegiatan positif di dalamnya.

\section{Referensi}

Ahmadi, Abu dan Noor Salim. 2008. Dasar-Dasar Pendidikan Agama Islam. Jakarta: PT Bumi Aksara

Alawiyah, Tutty. 1997. Strategi Dakwah di Lingkungan Majelis Taklim. Bandung: Mizan

Alim, Muhammad. 2006. Pendidikan Agama Islam. Bandung: PT Remaja Rosdakarya

Anwar, Desy. 2015. Kamus Lengkap Bahasa Indonesia. Surabaya: Amelia

Arifin, M. 2003. Ilmu Pendidikan Islam. Jakarta: Bumi Aksara

Arifin, Muzayyin. 2008. Kapita Selekta Pendidikan Islam. Jakarta: PT Bumi Aksara

Arifin, Syamsul. Bambang. 2015. Psikologi Agama. Bandung: CV Pustaka Setia

Basyiruddin, M. 2002. Metodologi Pembelajaran Agama Islam. Jakarta: Ciputat Pers

Daradjat, Zakiah. 2006. Imu Pendidikan Islam. Jakarta: Bumi Aksara.

Hadiawati, Lina. 2008. Pembinaan Keagamaan Sebagai Upaya Meningkatkan Kesadaran Siswa Melaksanakan Ibadah Shalat". Jurnal Pendidikan, Vol. 02, No. 01

Helmawati. 2013. Pendidikan Nasional Dan Optimalisasi Majelis Ta'lim. Jakarta: Rineka Putra

Hidayati, Nur. 1999. Imu Pendidikan Islam. Bandung: Pustaka Setia 
Kementerian Agama RI. 2014. Al-Qur'an Terjemah dan Tajwid. Kiaracondong Bandung: Sygma

Mahfud, Rois. 2011. AL-ISLAM Pendidikan Agama Islam. Palangka Raya: Erlangga

Marimba, Ahmad D. 1989. Pengantar Filsafat Islam. Bandung: PT. Al-Ma'arif

Maryatin. 2014. Efektifitas Metode Ceramah Dalam Penyampaian Dakwah Islam: Studipada Kelompok Pengajian di Perumahan Mojosongo Permai Kabupaten Boyolali, Jurnal Ilmu Dakwah, Vol. 34, No. 1, Januari-Juni ISSN 1693-8054

Meloeng, Lexy J. 2008. Metode Penelitian Kualitatif. Bandung: PT Remaja Rosda Karya

Milles, Matthew B. A. Michael Huberman. Jhonny Saldana. 2014. Qualitative Data Analysis, A Methods Sourcebook. California: SAGE Publication

Mubarok, Achmad . 2009. Psikologi Dakwah. Jakarta: Prenada Media Group

Muin, Abdul. 2008. Fenomena Pendidikan Keagamaan Masyarakat Tabanan Bali; Kasus Majelis Taklim Al- Falah, Jurnal Penelitian Pendidikan Agama dan Keagamaan Vol. 6, No 3 (Juli- September 2008)

Mujib, Abdul dan Jusuf Mudzakkir. 2010. Ilmu Pendidikan Islam. Jakarta: Kencana Prenada Media

Munir, M., Wahyu Ilahi. 2006. Manajemen Dakwah. Jakarta: Rahmat Semesta.

Rahmat, Aswary. 2018. Peranan Majelis Taklim Al-Munawwarah dalam Pembinaan Masyarakat Di Kelurahan Mosso Dhua Kecamatan Sendana Kabupaten Majene Provinsi Sulawesi Barat. Skripsi. UIN Alaudin Makasar

Sugiyono. 2015. Metode Penelitian Kuantitatif, Kualitatif, dan R\&D. Bandung: Alfabeta

Sugiyono. 2017. Metode Penelitian Kuantitatif, Kualitatif, dan R\&D. Bandung: Alfabeta

Tim Revisi. 2018. Pedoman Penulisan Karya Ilmiah. Jember: IAIN Jember Press.

Yakub, Ali Mustafa. 2000. Pendekatan Pendidikan. Jakarta: Pustaka Firdaus.

Zailani, Ahmad. 2019 Pembinaan Keagamaan Melalui Majelis Taklim Al-Hidayah di Desa Tapung Kecamatan Tandun Kabupaten Rokan Hulu. Skripsi. UIN SUSKA Riau Pekanbaru

http://digilib.mercubuana.ac.id/manager/t!@file_artikel_abstrak/Isi_Artikel_7187 93118976.pdf. (10 Desember 2019)

https://nurulhayat.org/majelis-talim-abang-becak, (10 November 2019) 